\title{
Age structure and growth in a large teleost, Cheilinus undulatus, with a review of size distribution in labrid fishes
}

\author{
J. H. Choat ${ }^{1, *}$, C. R. Davies ${ }^{2,3}$, J. L. Ackerman' ${ }^{1,4}$, B. D. Mapstone M, $^{2}$ \\ ${ }^{1}$ School of Marine Biology \& Aquaculture, and ${ }^{2}$ CRC Reef Research Centre, James Cook University, Townsville 4811, Australia \\ ${ }^{3}$ Present address: CSIRO Marine and Atmospheric Research, 203 Channel Highway, GPO Box 1538, Hobart, Tasmania 7001, \\ Australia \\ ${ }^{4}$ Present address: Bureau of Rural Sciences, Fisheries and Marine Sciences, GPO Box 858, Canberra ACT 2601, Australia \\ ${ }^{5}$ Present address: Antarctic Climate and Ecosystems, Cooperative Research Centre, Private Bag 80, Hobart, Tasmania 7001, \\ Australia
}

\begin{abstract}
Age-based demographic parameters were estimated from 164 individuals of the large teleost Cheilinus undulatus from NE Australia. Analysis of sagittal otoliths revealed alternating translucent and opaque bands in which annual periodicity of a single opaque band was confirmed. A size-at-age plot of 164 individuals showed that males grew significantly faster than females, achieving a size of $140 \mathrm{~cm}$ fork length (FL). Male growth trajectories were essentially linear. Maximum ages recorded were $25 \mathrm{yr}$ for males and $30 \mathrm{yr}$ for females. Estimates of annual total mortality ranged from 0.10 to 0.14 . The age distribution of males suggests protogyny with male recruitment into the population commencing at $9 \mathrm{yr}$ at a size threshold of $70 \mathrm{~cm}$. The age distribution of females confirmed that not all individuals changed sex. Analysis of the sample size revealed a strongly skewed distribution with a modal size peak at 50 to $70 \mathrm{~cm}$ and an extended tail of larger individuals. Estimates of size distributions from underwater surveys revealed a right-skewed distribution similar to that observed in our sample. An analysis of size distributions in labrid fishes shows that large size ( $>75.0 \mathrm{~cm} \mathrm{FL)}$ is rare ( $4.5 \%$ of 559 species). Demographic analysis of C. undulatus and of large labrid fishes demonstrates that they share a dynamic demography with fast indeterminate growth rates and relatively short life spans.
\end{abstract}

KEY WORDS: Cheilinus undulatus - Size distribution - Age based demography - Growth rates · Validation $\cdot$ Maximum age $\cdot$ Labrid size distribution $\cdot$ Fishing effects

\section{INTRODUCTION}

Body size is an important variable in fisheries ecology as it provides a basis for predicting life history features including longevity, growth and mortality rates (Roff 1992, Charnov 1993, Froese \& Pauly 2000). Moreover very large fishes may be highly vulnerable to fishing (Jennings et al. 1999, Dulvy et al. 2003). This is especially true of coral reef fishes where large species are increasingly targeted by commercial fisheries including the live reef fish trade (Sadovy \& Vincent
2003, Sadovy et al. 2004). Coral reef fish are similar to other fish assemblages in that they are dominated by small individuals with strongly right-skewed size distributions (Munday \& Jones 1998, Froese \& Pauly 2000 ) to the extent that sizes $>100 \mathrm{~cm}$ are highly unusual. Despite their relative rarity, very large coral reef fishes attract a considerable degree of attention in the context of fisheries management and conservation.

Size data often represents the only information available for the management of large species. This is because of low abundances and the difficulties associ- 
ated with collecting adequate samples. However, reef fishes display variable growth rates and strong phylogenetic patterns in life history data, especially longevity (Choat \& Robertson 2002). For these reasons it is unwise to predict life history features on the basis of body size alone. Further, age-based demographic data are necessary for the management and conservation of tropical fishes.

The maori wrasse Cheilinus undulatus is one of the largest teleost fishes associated with coral reef environments. Cheilinus is a widespread Indo-Pacific genus of wrasses comprising a clade of 7 species (Westneat 1993, Parenti \& Randall 2000). All are closely associated with coral reef environments and display a wide size range of maximum sizes ranging from $17 \mathrm{~cm}$ fork length (FL) in C. oxycephalus to $150 \mathrm{~cm} \mathrm{FL} \mathrm{in} \mathrm{C.} \mathrm{undu-}$ latus. The geographical distribution of $C$. undulatus extends through the Red Sea, Indian and Pacific oceans to the Line, Marshall, Cook and Tuamoto islands (Sadovy et al. 2004). C. undulatus occurs in relatively shallow reef areas, primarily reef fronts and passes. In a review of all available information on this species, Sadovy et al. (2004) concluded that C. undulatus manifested low abundances, even in undisturbed environments, and had an extended life span and a complex sexual ontogeny with evidence of protogyny.

Sadovy et al. (2004) also identified adverse impacts of fishing over much of the species range, particularly in SE Asia. Despite the comprehensive nature of this review, the extent to which adverse impacts of fishing were attributable to conservative life history features including extended life spans and late achievement of sexual maturity or other factors such as rarity remains unresolved. This reflects the paucity of age-based demographic information on large reef species. Agebased information is critical not only because it allows demographic comparisons by habitat, regions, and taxonomic groupings, but also because it provides a time frame for predicting rates of recovery if protection from fishing is established, a potentially controversial topic (Halpern \& Warner 2002, Russ \& Alcala 2004).

Accordingly, the focus of the present study is an analysis of the age-based demography of NE Australian populations of Cheilinus undulatus. The primary goal was to estimate age-specific growth and mortality rates, age at maturity, and life span in this population. Sadovy et al. (2004) argue that the adverse impacts of fishing, especially in the western Pacific and Asian distributional range, reflects the combination of conservative life-history features characteristic of this species. However, labrid fishes including wrasses and parrotfishes have a characteristically dynamic demography where rapid growth rates, especially in males, are linked to relatively high mortality rates and reduced life spans (Hotstetter \& Munroe 1993, Choat et al. 1996, 2003, Choat \& Robertson 2002). The extent to which these features vary with increase in body size is a matter of considerable interest.

Large size has been recorded in a number of labrid species including the Indo-Pacific parrot fish Bolbometopon muricatum, the tropical Atlantic hogfish Lachnolaimus maximus and temperate water species including Semicossyphus pulchrum and Achoerodes gouldii. Are these species typical of the wider range of labrid fishes or are they outliers? To put the issue of large size in Cheilinus undulatus into a more general context we have reviewed the distribution of sizes within the labrid fishes. Additional interest in the pattern of size distribution in labrid fishes has been generated by a recent re-evaluation of phylogenetic relationships. Cheiline wrasses, which include C. undulatus, form a clade with the morphologically distinctive parrotfishes (scarines), a group also characterised by large body size (Clements et al. 2004, Westneat \& Alfaro 2005).

Given the problems involved in obtaining large samples of this species from specific localities, we have taken the opportunity to include as much information as possible from each individual sampled. This includes dietary analyses and reproductive material. Preliminary analysis of the reproductive material is presented here. A more detailed study will be presented in later publications. Our study deals with the following aspects of the biology of Cheilinus undulatus:

(1) Dietary analyses that provide a comparison with feeding studies from other locations (Randall 1978). (2) Demographic analyses including estimates of maximum age, size structure, rates and patterns of growth partitioned by sex, and the relationship between age and size with respect to female maturity and the recruitment of males into the sampled populations. (3) A review of distribution of body sizes in the labrids in order to put the distinctive size structure of Cheilinus undulatus into a more general context. (4) A discussion of the phylogenetic status and relationships of the major groups of labrid fishes to determine the evolutionary relationships associated with large size (here defined as $>75 \mathrm{~cm} \mathrm{FL).}$

\section{MATERIALS AND METHODS}

Terminology. Recent phylogenetic analyses of relationships amongst groups previously identified as the families Labridae, Scaridae and Odacidae (Clements et al. 2004, Westneat \& Alfaro 2005) have confirmed the hypothesis of Kaufman \& Liem (1982) that these families formed a monophyletic group and should be combined into a single family, the Labridae. A consequence of this analysis is that the Labridae sensu Norman (1966) must now be considered paraphyletic. 
In terms of consistency it is now appropriate to reserve the term Labridae for the clade containing the wrasses, parrot fishes and weed whitings (odacines). The most appropriate terminology for the within-clade classification is that proposed by Gomon (1997) who subdivided the 3 taxa into 10 tribes including the scarines and odacines.

Sampling and study localities. With the exception of 1 juvenile of $73 \mathrm{~mm}$ FL obtained from Bali (aquarium dealer) all specimens sampled for demographic information were obtained from the northern and central regions of the Great Barrier Reef from 14 to $22^{\circ} \mathrm{S}$. A total of 178 Cheilinus undulatus were sampled for this study through the period 1995 to 2002 partitioned by sampling method and locality as shown in Table 1. Age estimates and otolith weights were obtained from 164 of the 178 individuals collected, sexual identity from 140 individuals, and gonad weights from 134 individuals.

Estimates of maximum size. The literature contains a number of reports of Cheilinus undulatus achieving lengths $>200 \mathrm{~cm}$ FL (Sadovy et al. 2004). The largest individual sampled in this program was $142 \mathrm{~cm}$ FL and the maximum size recorded from unfished populations in the Solomons was $150 \mathrm{~cm}$ FL (R. Hamilton pers. comm.). The most frequently cited record of maximum size for this species is based on the report by Marshall (1966), who recorded that a 'blue-tooth groper' of 7' 6", 420 lbs $(228 \mathrm{~cm}, 190 \mathrm{~kg})$ was taken at Hayman Island. According to Marshall (1966), 'It seems probable...was a Maori Wrasse'. This record was repeated by Grant (1997). Despite a comprehensive survey of fisheries and field based records (Sadovy et al. 2004) there are no confirmed records of this species greater than $150 \mathrm{~cm}$ FL.

Table 1. Cheilinus undulatus. Source and location of specimens used in this study. FL: fork length; CRC: Cooperative Research Centre; GBR: Great Barrier Reef; JCU: James Cook University; GBRMPA: Great Barrier Reef Marine Park Authority

\begin{tabular}{|c|c|c|c|}
\hline Source and location & Method & Number & $\begin{array}{l}\text { Size range } \\
\text { FL }(\mathrm{cm})\end{array}$ \\
\hline $\begin{array}{l}\text { CRC Effects of Line Fishing } \\
\text { program, GBR } 14-22^{\circ} \mathrm{S}\end{array}$ & $\begin{array}{l}\text { g Line } \\
\text { fishing }\end{array}$ & 120 & $36-129$ \\
\hline $\begin{array}{l}\text { JCU Marine Biology } \\
\text { program, GBR } 14-18^{\circ} \mathrm{S}\end{array}$ & Spearing & 37 & $24.3-111$ \\
\hline $\begin{array}{l}\text { Commercial Fishery, } \\
\text { GBR } 14-20^{\circ} \mathrm{S}\end{array}$ & $\begin{array}{l}\text { Line } \\
\text { fishing }\end{array}$ & 10 & $75-138.3$ \\
\hline $\begin{array}{l}\text { Recreational Fishery, } \\
\text { GBR } 14-20^{\circ} \mathrm{S}\end{array}$ & Spearing & 7 & $56-142$ \\
\hline $\begin{array}{l}\text { Aquarium Trade, } \\
\text { GBR and Bali }\end{array}$ & Netting & 2 & $6.2-7.3$ \\
\hline $\begin{array}{l}\text { GBRMPA Aquarium, } \\
\text { GBR }\end{array}$ & Netting & 2 & $99-127$ \\
\hline
\end{tabular}

Ageing and growth. All individuals were measured (standard length [SL] and FL in $\mathrm{mm}$ ) and weighed to the nearest $g$ where possible though some specimens could be weighed on capture only to the nearest $10 \mathrm{~g}$. There was a consistent relationship between SL and FL with SL 0.794 of FL $(n=20)$. Sagittal otoliths were removed, cleaned and stored dry. One sagitta from each pair was weighed to the nearest $0.1 \mathrm{mg}$. The procedures for otolith processing and sectioning are provided in Choat et al. (2003). Sectioned otoliths were examined under both high power and dissecting microscopes using transmitted light. Each otolith was read 3 times for annuli by a single observer. In cases where the disparity between counts was $\geq 20 \%$ an additional count was made by a second observer. Counts were made along a consistent axis (Choat \& Axe 1996).

Growth curves were generated from size at age data obtained from the analysis of 164 sagittal otoliths. Growth parameters were estimated by fitting the von Bertalanffy growth function (VGBF): $L_{t}=L_{\infty}(1-$ $\exp \left(-k_{\left(t-t_{0}\right)}\right)$ where $L_{t}$ is the estimated fork length at age $t, L_{\infty}$ is the mean asymptotic standard length, $k$ is a curvature parameter and $t_{0}$ is the age at which fish have theoretical length of zero. Growth parameters were estimated using the iterative non-linear least squares method. Because VBGF parameter estimates can be sensitive to the range of ages and sizes used (Ferreira \& Russ 1994, Craig 1999), the intercept was constrained to $0 \mathrm{~cm}$. The relationship between otolith weight and increment number was examined using regression analysis.

Comparison of size and age among sexes was accomplished in 2 ways. Mean estimates of VBGF parameters $L_{\infty}$ and $k$ and their confidence intervals were obtained by bootstrapping with 1000 iterations. However, for males due to the linear pattern of growth and the lack of individuals younger than $9 \mathrm{yr}$, the use of VBGF parameters for this sex was unrealistic. As an alternative, linear equations were fitted to male and female size at age relationships and growth rates ( $\mathrm{mm} / \mathrm{yr}$, defined by the linear regressions) between mature males and mature females were tested using an analysis of covariance. For consistency between the age groups of the males and females, only those females $\geq 9$ yr of age were used in the analysis.

Total mortality $(Z)$ and survivorship rates $(S)$ were calculated in 2 ways: (1) using log-linear regression analyses of age frequency data where $S=\mathrm{e}^{-Z}$, and (2) $Z=\ln (100) / t_{\max }$, where $t_{\max }$ is the maximum longevity in the sample (Hilborn \& Walters 1992). For the agefrequency data (generated from the 164 specimens that were aged) only fish that had recruited into the sampling regime (>6 yr age) were used. It was not possible to obtain a realistic measure of fishing mortality 
as the study population is very lightly fished; thus total mortality was estimated.

Annual periodicity of check-marks observed in sagittal otoliths was validated by tetracycline marking of individuals maintained in an aquarium. Given the large size and relative rarity a field based validation program was not possible.

Two adult individuals (estimated lengths 90 and $91 \mathrm{~cm} \mathrm{FL)} \mathrm{injected} \mathrm{with} \mathrm{oxytetracycline} \mathrm{were} \mathrm{main-}$ tained in a circulating seawater system tank with a capacity of $160000 \mathrm{l}$ circulated 6 to 8 times every $24 \mathrm{~h}$ through a system of algal scrubbers and biological filtration. Details for each individual were as follows: Both individuals were captured on the Great Barrier Reef $18^{\circ} \mathrm{S}$ in early October 1997, transported in an aerated tank to the JCU campus and injected with tetracycline on 14 October 1997, and released into the $160000 \mathrm{l}$ tank. The larger fish died on 24 August 1998 at $94.4 \mathrm{~cm}$ FL. The other fish was given a second injection of tetracycline on 25 November 1999 and killed on 31 July 2000 (FL $99.5 \mathrm{~cm}$ ), 1020 d after the first injection of tetracycline. Strong tetracycline bands were observed in the sectioned sagittal otoliths of each individual with the double marked individual showing 2 fluorescent bands.

The model of Cappo et al. (2000) was used to obtain estimates of the periodicity of opaque zone completion. In summary this model proposes that if each translucent/opaque zone ( 1 cycle) is equivalent to $1 \mathrm{yr}$, then the distance from the tetracycline mark to the outer edge of the otolith, divided by the width of the last complete cycle should equal the time from mark to recapture. Following Cappo et al. (2000) the initial fractions $(I F)$ and final fractions $(F F)$ of otolith growth were estimated as follows:

$I F=\left(R_{a}-T\right) /\left(R_{a}-R_{a-1}\right)$, and $F F=\left(R-R_{a}\right) /\left(R_{a}-R_{a-1}\right)$

where $a=$ the age of the fish, $R=$ radius to the edge, $R_{a}=$ radius to the final opaque zone, and $T=$ radius to the OTC mark. The cycle frequency $(V)$ estimates the number of increment cycles completed per year as:

$$
V=(I F+F F+N) / L
$$

where $N=$ number of full increment cycles outside the OTC mark, and $L=$ the time at liberty.

Gonads were dissected from the body cavity from freshly caught, or (more rarely) frozen fish, and weighed to the nearest gram. Dietary analyses were carried out on specimens captured on reef fronts during daylight hours of 10:00 to $17: 00 \mathrm{~h}$. These did not include individuals associated with reproductive activity. Contents of the entire alimentary tract were removed and preserved in $10 \%$ formaldehyde. Contents were sorted and identified to genus where feasible. The percentage cover of each food item in the sort- ing dish was estimated using the transect methodology of Choat \& Clements (1992) and expressed as mean\% cover to obtain the relative abundance of each item.

Preliminary abundance estimates (for 1994/1995 and 2001 on outer reefs of the northern GBR adjacent to Lizard Island) were obtained by visual surveys of replicated belt transects $400 \times 20 \mathrm{~m}$ with start and finish points determined by GPS. For 1994/1995 a total of 24 transects partitioned between 3 outer reef sites were made. In 2001 sixteen transects were partitioned between 4 sites. All Cheilinus undulatus $>30 \mathrm{~cm}$ FL were counted within the transect area and FL estimated to the nearest $10 \mathrm{~cm}$.

\section{RESULTS}

The 178 Cheilinus undulatus sampled for this study showed a strongly right-skewed size frequency distribution. The majority of sampled individuals were between 40 and $70 \mathrm{~cm}$ FL (Fig. 1) with a modal length of 50 to $59 \mathrm{~cm}$. Very few specimens $<30 \mathrm{~cm}$ FL were collected. This sampling bias probably reflects the cryptic behaviour of juvenile $C$. undulatus and their habitat preferences for sheltered lagoonal environments vs. exposed reef slopes favoured by adults. The dominance of individuals between 50 and $70 \mathrm{~cm} \mathrm{FL}$ and the long tail of uncommon, larger individuals reflected size frequencies in the field (see below).

Analysis of alimentary tract contents of 17 individuals collected by spearing confirmed a diet dominated by larger invertebrates (crustaceans, molluscs and echinoderms) with some evidence of feeding on benthic fishes. The proportions of the prey items recorded for this population were crustaceans 29, molluscs 20, fishes 12 and echinoderms $3 \%$.

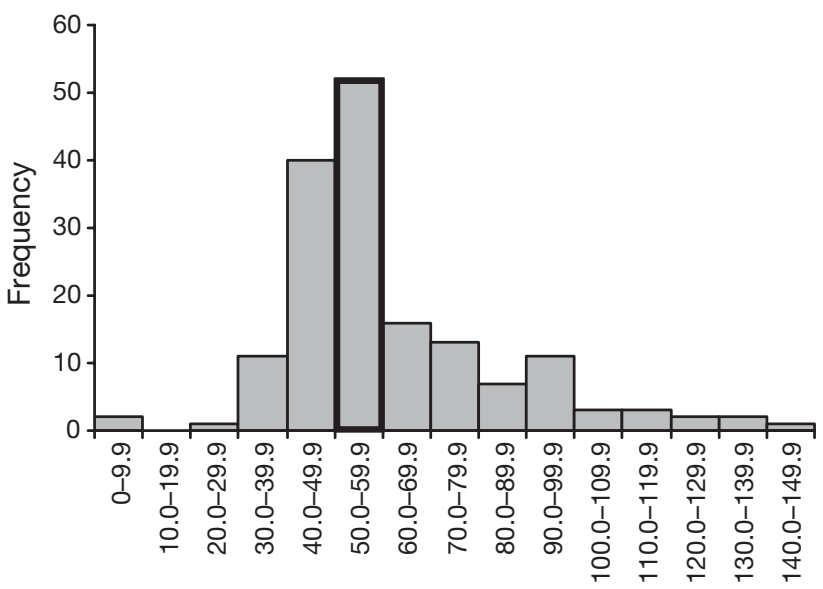

Fork length $(\mathrm{cm})$

Fig. 1. Cheilinus undulatus. Size frequency distribution $(\mathrm{n}=$ 164) of all individuals used in the study. Highlighted bar: modal length 

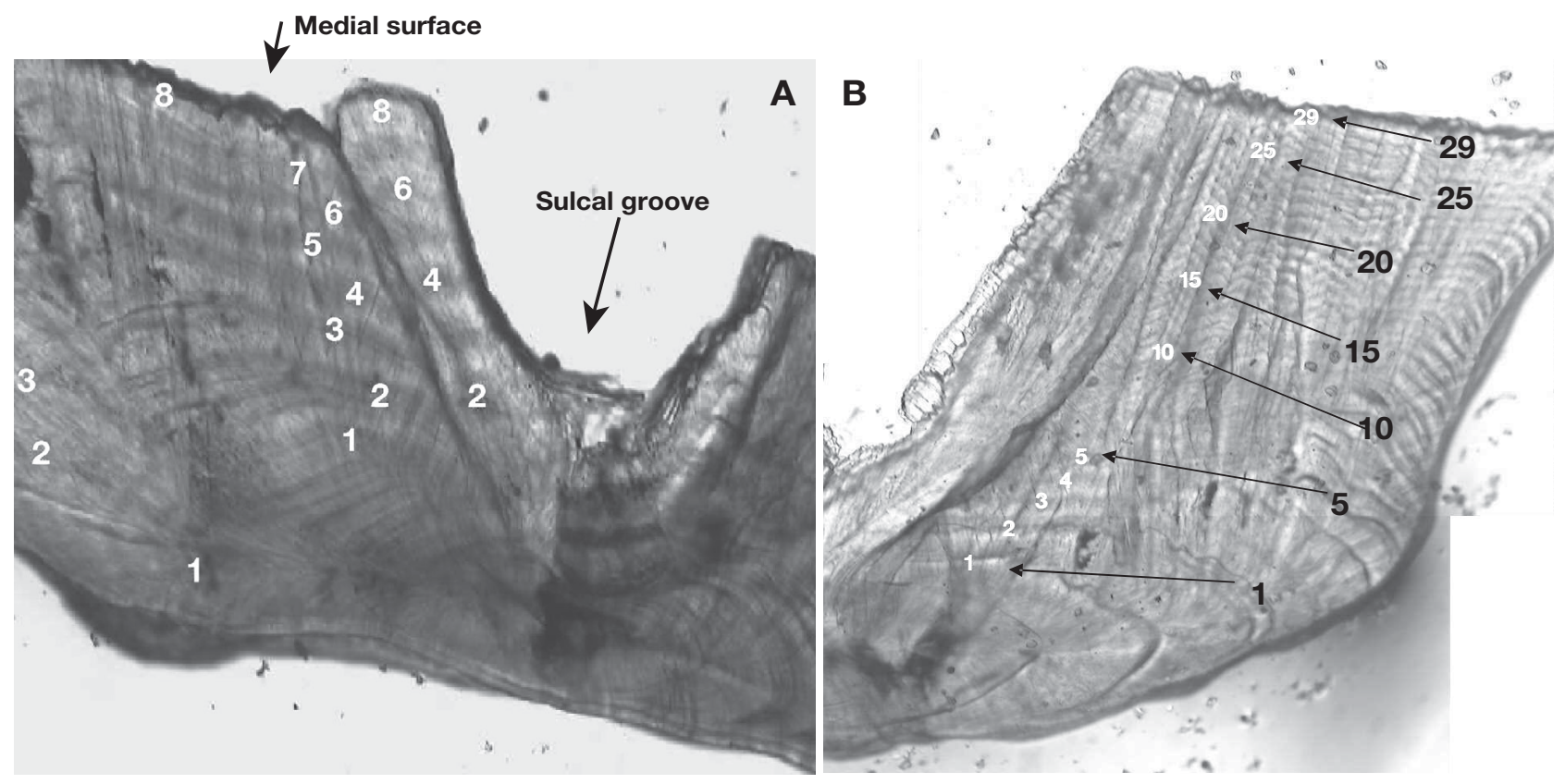

Fig. 2. Cheilinus undulatus. Sectioned sagittal otolith of (A) an $8 \mathrm{yr}$ old female (56.5 cm fork length [FL]), and (B) a $29 \mathrm{yr}$ old female ( $76.5 \mathrm{~cm} \mathrm{FL)}$

Sagittal otoliths collected from 164 individuals were examined for growth increments in sectioned sagittae. Sectioned otoliths had a highly characteristic appearance with a deep sulcal groove on the medial face of the sagitta of larger individuals. Growth increments were visible as opaque bands in the matrix of the sectioned otolith when viewed under transmitted light. Opaque bands characteristically became more narrowly spaced toward the medial region of the sagitta and were readily counted on either side of the sulcal groove (Fig. 2). Specimens collected from up to $15^{\circ} \mathrm{S}$ displayed well-defined increments in sectioned sagittae. Tetracycline injections on 2 individuals were carried out in order to validate the annual frequency of opaque increments seen in sections of sagittal otoliths. The first (double injected) showed 2 clear tetracycline marks under fluorescent light. The second individual showed a single clear tetracycline band. The estimated cycle frequency V (Cappo et al. 2000) for formation of opaque check marks was estimated as 1.06 and $1.10 \mathrm{yr}$, respectively. Based on this result the opaque bands observed in sectioned sagittae were inferred to be annual increments.

Regression of otolith weight on the estimated age of fish provided a linear plot with $\mathrm{r}^{2}=0.89$ (Fig. 3). A size at age plot was constructed using the 164 individuals for which age estimates were obtained (Fig. 4). The plot exhibited increasing variability in the relationship between size and age. Partitioning the plot by sex demonstrated that this variability was due to increasingly divergent growth trajectories between males and females.
VBGF estimates for $k$ and $t_{0}$ are sensitive to the distribution of age data at the lower end of the size range (Ferriera \& Russ 1994, Choat \& Robertson 2002). As males appear to recruit into the population only after $\sim 9 \mathrm{yr}$ there were problems in fitting VBGF by sex. Therefore, we analysed the size-at-age data in 2 ways: fitting separate VBGF to male and female data gave $L_{\infty}$ estimates of $75.5 \pm 17.4 \mathrm{~cm}$ FL for females, and $396.8 \pm$ $2046.0 \mathrm{~cm}$ FL for males. These estimates are realistic for females and confirm the asymptotic growth pattern. However the distribution of $L_{\infty}$ estimates for males was highly skewed resulting in very large confidence intervals. Moreover the mean estimate for male size was far greater than that observed in unfished populations.

Linear plots adequately described the size at age relationships for sexually mature individuals over the age distribution sampled for both sexes. For females

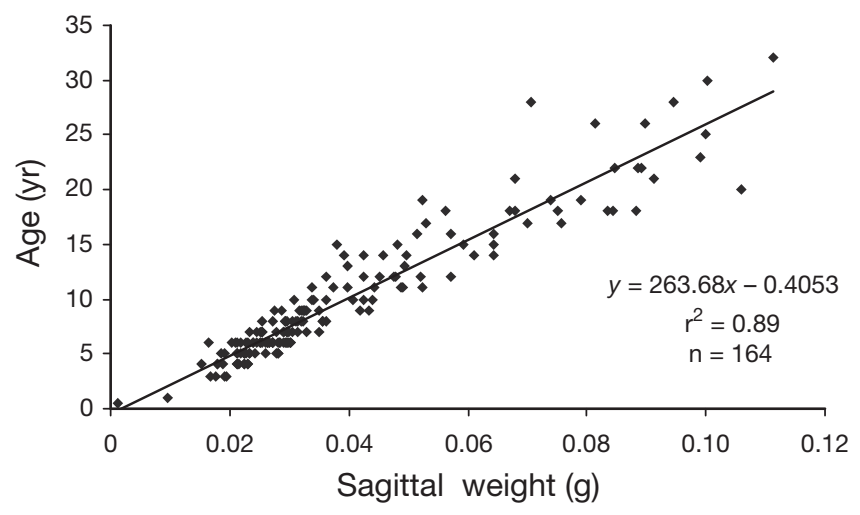

Fig. 3. Cheilinus undulatus. Regression of sagittal otolith weight on age $(\mathrm{n}=164)$ 


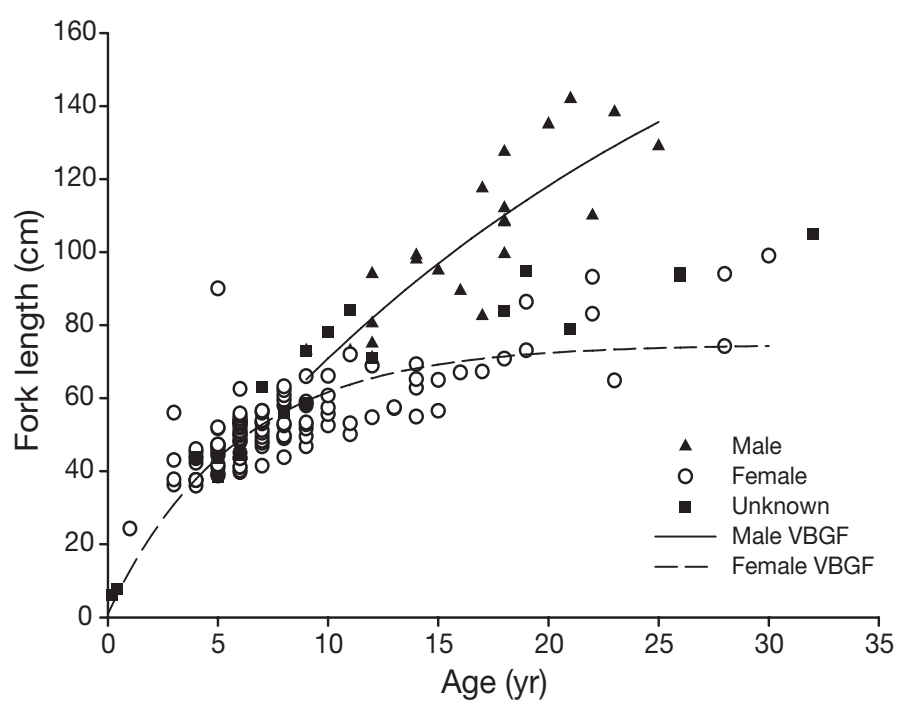

Fig. 4. Size at age plot partitioned by sex with fitted von Bertalanffy growth function (VBGF) curves. Size at $t_{0}$ constrained to 0. 'Unknown': samples in which sex was not verified

the range of ages was from 3 to $30 \mathrm{yr}$ (see below) and from 9 (the youngest male recruit in the population) to 25 yr for males. For comparative purposes we analysed the relationship between size and age for females between 9 and $30 \mathrm{yr}$ and between 9 and $25 \mathrm{yr}$ for males. The linear relationship between age and size for sexually mature females was $y=17.9 x+388.3\left(\mathrm{r}^{2}=\right.$ $0.67)$ and for males was $y=44.6 x+285.4\left(r^{2}=0.71\right)$. Estimated growth rates for each sex (females $17.9 \pm$ $2.1 \mathrm{~mm} \mathrm{yr}^{-1}$, males $44.6 \pm 14.4 \mathrm{~mm} \mathrm{yr}^{-1}$ ) showed male growth rates were approximately double those of females resulting in relatively young but large males. ANCOVA revealed highly significant differences $(\mathrm{p}=$ 0.00002) between the slopes.

The age frequencies generated for the size at age plot provided an age-based catch curve for fish $5 \mathrm{yr}$ and older. The annual total mortality estimate from the regression analysis $\left(y=-0.1081 x+3.151, r^{2}=0.7243\right)$ was $Z=0.11$ with $95 \%$ confidence intervals of \pm 0.03 ,

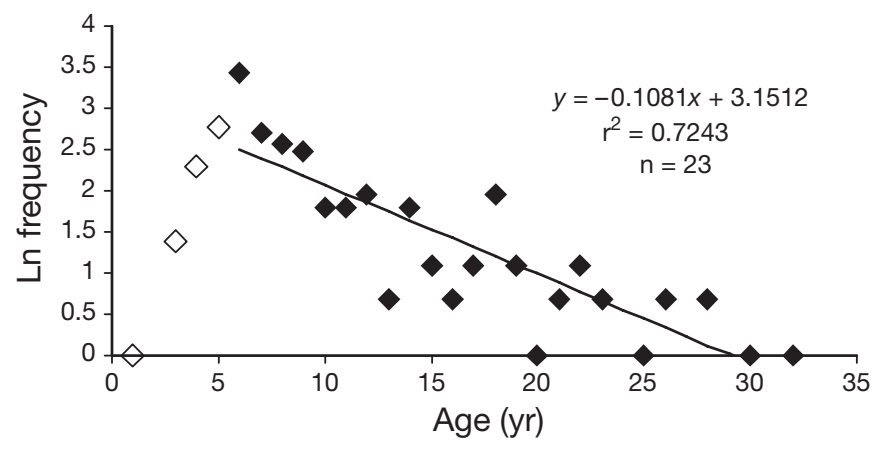

Fig. 5. Cheilinus undulatus. Regression of age classes on Ln frequency of each age class for estimation of total mortality $Z$ suggesting that $<3.5 \%$ of Cheilinus undulatus from the study population live beyond $30 \mathrm{yr}$. (Fig. 5). A second mortality estimate using the formula $M=\ln (100) / t_{\max }$ gives an estimate of mortality at 0.14 with $<1.5 \%$ of the population living to $30 \mathrm{yr}$. Both results suggest that very few $C$. undulatus in the study area achieve an age $>30$ yr.

The distribution of age frequencies derived from the whole collection suggested a population dominated by young females with a modal peak in abundance between 50 and $60 \mathrm{~cm}$ (Fig. 1). Underwater counts revealed size frequencies with the same structure as the catch sample, both populations were dominated by small fish (presumably females) and relatively low numbers of large individuals (identified as males by colour pattern; Fig. 6). The main difference was that the catch data showed a greater proportion of small individuals (45 to $55 \mathrm{~cm}$ FL) than recorded in the visual surveys. This results from cryptic behaviour of small fish. The maximum size of males obtained from catch data was also greater than observed in counts possibly because the catch samples were taken from a wider area.

Analysis of gonad weights for both females and males revealed the same bipartite relationship between ovary and testis weight and fish size observed in other protogynous labroid fishes (Fig. 7). Ovary weight abruptly increased at approximately $55 \mathrm{~cm}$ FL and at an age between 6 and $7 \mathrm{yr}$, indicating that female sexual maturity first occurred at this combination of age and sizes. The youngest male observed in the population was $9 \mathrm{yr}$ and approximately $70 \mathrm{~cm}$ FL. In both sexes the relationship between gonad weight and fork length was highly variable. An exponential equation was fitted to ovary weight and FL whilst for testis weight the most appropriate equation was linear. In

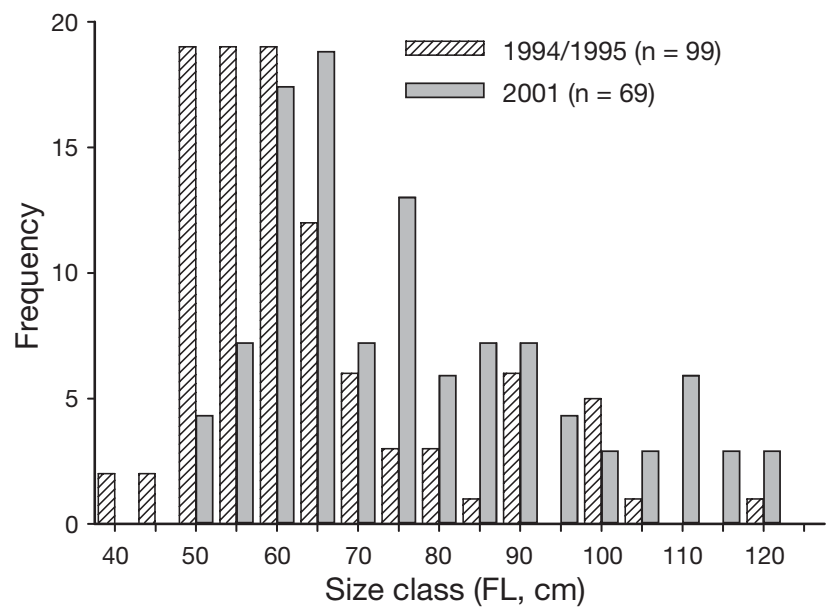

Fig. 6. Cheilinus undulatus. Estimates of abundance showing size frequencies of individuals during visual surveys over 2 sampling periods on NE Australian reefs. 1994/1995: 24 transects partitioned between 3 outer reef sites; 2001: 16 transects partitioned between 4 sites. FL: fork length 


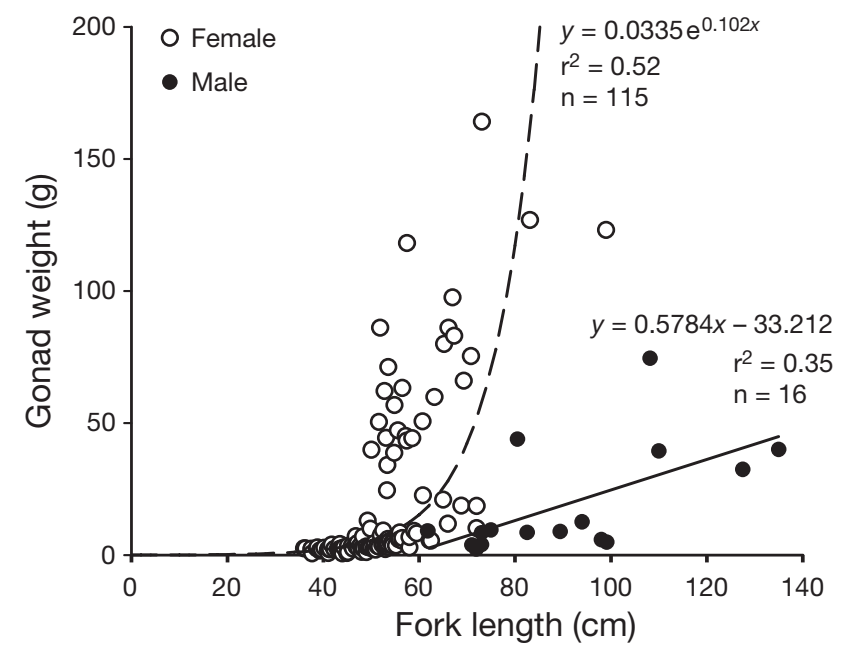

Fig. 7. Cheilinus undulatus. Regression of fork length on gonad weight partitioned by sex. An exponential and a linear equation were fitted to the biplots for females and males respectively

both instances the $\mathrm{r}^{2}$ values were relatively low. The differing relationships between ovary (exponential) and testis (linear) weights and body length in Cheilinus undulatus are characteristic of a number of protogynous species.

\section{DISCUSSION}

Our discussion focuses on 3 questions arising from this study: What is the basis of large size in Cheilinus undulatus? What is the pattern of distribution and evolutionary relationships of large size in labrid fishes? Which life history features of $C$. undulatus make them vulnerable to overfishing?

Size increase may be achieved through rapid growth resulting in large but relatively young individuals, or growth may be slower with increased longevity providing an opportunity to reach large sizes. Given the pattern of indeterminate growth characteristic of labrid fishes (Choat \& Robertson 2002) each of these alternatives could apply to Cheilinus undulatus. Our data show that large size is achieved through rapid growth resulting in populations characterised by very large but relatively young individuals. As with many species of labrid fishes (Choat et al. 1996) growth is highly sex-specific, with males growing faster than females. Initial growth rates in C. undulatus are relatively rapid resulting in a size of $50 \mathrm{~cm}$ at approximately $7 \mathrm{yr}$. In the study populations males appeared at 9 yr of age and manifested a rapid and essentially linear growth rate resulting in the very large $(>100 \mathrm{~cm})$ fish that characterize undisturbed C. undulatus populations. Females had slower growth rates with a more pronounced asymptote with very few individuals achieving sizes $>100 \mathrm{~cm}$. The pattern of sexspecific growth in this species with very rapid increases in size in secondary males demonstrates that it may not be possible to routinely analyse such species using VBGF parameters. The extent to which this is characteristic of other labrid fishes requires confirmation.

The size at age plots demonstrate that sizes in the order of $100 \mathrm{~cm}$ are achieved in males after $16 \mathrm{yr}$, a relatively short time period for many coral reef fishes (Choat \& Robertson 2002). The total life span is modest with a maximum of $30 \mathrm{yr}$ for females and only $25 \mathrm{yr}$ for males. In males the maximum life span following recruitment via sex reversal was 16 yr during which time growth was essentially linear. Greater life spans are achieved by much smaller temperate (Cooper 1967, Lowry 2003) and deepwater (Cailliet 2001) fishes.

It is now possible to put the issue of large size in Cheilinus undulatus into a more general context by examining the evolutionary and habitat relationships that underlie size distributions in labrid fishes. Of a total of 559 described species (Parenti \& Randall 2000) that now constitute the monophyletic assemblage of labrid fishes (Clements et al. 2004) (453 wrasses, 94 scarines, 12 odacines) only $4 \%$ achieved the $75 \mathrm{~cm}$ threshold of large size. The size distribution within the entire group is right-skewed with a modal size of approximately $15 \mathrm{~cm}$ (Fig. 8). Large species are clearly outliers. The phylogeny allows a preliminary analysis of evolutionary relationships associated with large size. Size $>100 \mathrm{~cm}$ is restricted largely to 3 groups of labrids, hypsigenyines that contain the genera Lachnolaimus, Achoerodus, Bodianus, Semicossyphus and Choerodon, the cheilines (the tribe that contains $C$.

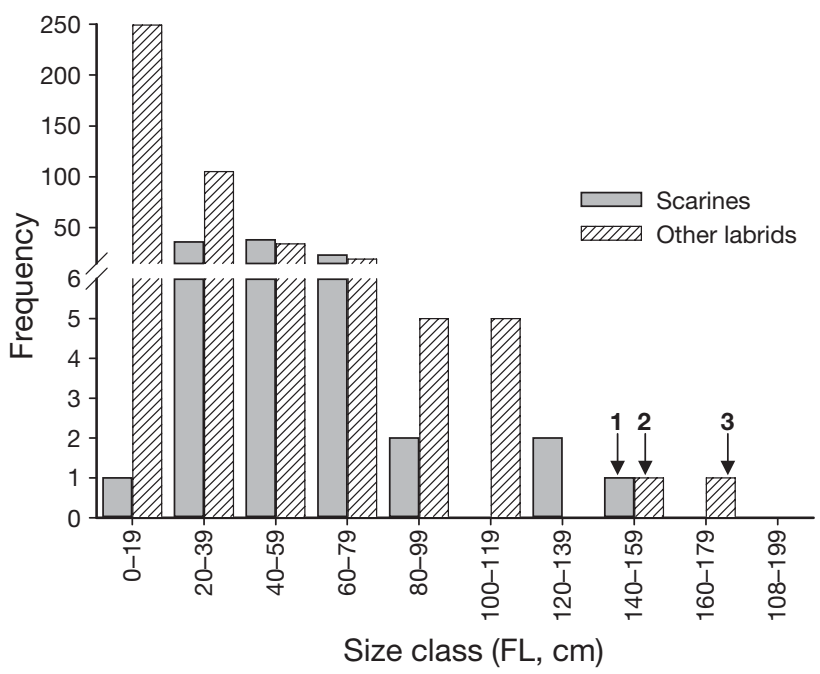

Fig. 8. Frequency distribution of length in 559 species of labrids partitioned by scarines versus the remaining 9 tribes following Gomon (1997). Note scale change in $y$-axis. $1=$ Cheilinus undulatus, 2 = Bolbometopon muricatum, 3 = Achoerodus gouldii. FL: fork length 
undulatus) and the scarines that contain the very large parrotfishes Bolbometopon and Cetoscarus. In evolutionary terms $C$. undulatus is more closely related to the ecologically and morphologically distinctive large parrot fishes, Bolbometopon muricatum and Cetoscarus bicolor, than to other large wrasses including the hypsigenyines.

Of the 22 large species recorded in this survey 8 were scarines, all of which are associated with coral reefs, 11 hypsigenyines, 1 labrine, 1 cheiline and 1 julidine (Table 2). Most of the labrid species that attain large size in shallow reef habitats are in the cheiline/ scarine clade. Many of the large hypsigenyine wrasses are restricted to subtropical and temperate environments, often occurring in deeper water. Demographic analyses of the scarines (Choat et al. 1996, Choat \& Robertson 2003) show that large species display the same dynamic demography as Cheilinus undulatus with indeterminate growth, relatively rapid sex-specific growth rates and comparatively short life spans implying rapid population turnover.

A recent review of Cheilinus undulatus biology and fishing practices shows that this species is strongly impacted by commercial fishing in the western Pacific and SE Asia (Sadovy et al. 2004). Conservative life history features including slow growth and extended life spans have been invoked as one of the reasons for the deleterious impacts of fishing (Sadovy et al. 2004).
Hostetter \& Munroe (1993) have made similar arguments relating to life history features in large labrids. An analysis of the large temperate labrine Tautoga onitis recorded a maximum age of $25 \mathrm{yr}$. The maximum age attributed to this species is $34 \mathrm{yr}$ (Cooper 1967 , Froese \& Pauly 2000). The greatest size and age achieved by this species occurred in males (Hostetter \& Munroe 1993). This study reviewed growth rates and life spans in other large temperate-water labrids. Two conclusions were drawn (1) for northern temperate labrids growth rates were slow and associated with extended longevities and (2) these characteristics may be an inherent feature of large-sized labrids in general. However more recent analyses of longevity in coral reef fishes (Newman et al. 1996, 2000, Meekan et al. 2001, Choat \& Robertson 2002) show that 30 yr is not particularly old. Moreover, growth rates in labrids appear to be comparatively rapid, even in cold-water species (Hostetter \& Munroe 1993, Gordoa et al. 2000).

What other factors are potentially responsible for the impacts of fishing on Cheilinus undulatus populations? The size and age-specific distribution of sexes in C. undulatus supports the conclusion of protogyny (Sadovy et al. 2004) in this species. Complex sexual ontogenies could increase the impact of fishing (Roberts \& Hawkins 1999). However, the demographic characteristics of males suggest that the study population is capable of a rapid response to male depletion,

Table 2. Labrids $>75 \mathrm{~cm}$ fork length. Higher order classification follows Gomon (1997). Authorities for maximum size estimates: Froese \& Pauly (2003), or as marked. Taxonomy follows Parenti \& Randall (2000)

\begin{tabular}{|c|c|c|c|c|c|c|}
\hline Classification & Species & $\begin{array}{l}\operatorname{Max} F L \\
\text { (cm) }\end{array}$ & Location & Coordinates & Habitat & $\begin{array}{c}\text { Depth } \\
\text { (m) }\end{array}$ \\
\hline \multirow[t]{11}{*}{ Hypsigenyines } & Achoerodes gouldii & 175 & SW Australia & $27-38^{\circ} \mathrm{S}$ & Temperate to subtropical reefs & $2-40$ \\
\hline & Achoerodes viridis & 100 & SE Australia & $25-38^{\circ} \mathrm{S}$ & Temperate to subtropical reefs & $2-40$ \\
\hline & Anchichoerops natalensis & 75 & $\mathrm{~S}$ Africa & $27-37^{\circ} \mathrm{S}$ & Temperate to subtropical reefs & $5-60$ \\
\hline & Bodianus diplotaenia & 76 & E Pacific & $10-32^{\circ} \mathrm{N}$ & Subtropical reefs & $5-75$ \\
\hline & Bodianus macrognathos & $80^{\mathrm{a}}$ & NW Indian Ocean & $5-20^{\circ} \mathrm{N}$ & Coral and deeper reefs & $3-65$ \\
\hline & Bodianus perditio & 80 & Subtropical & $25^{\circ} \mathrm{N}-35^{\circ} \mathrm{S}$ & Deeper reefs & $15-60$ \\
\hline & Choerodon schoenleinii & 100 & Tropical NW \& SW Pacific & $30^{\circ} \mathrm{N}-25^{\circ} \mathrm{S}$ & Coral reefs & $5-30$ \\
\hline & Choerodon rubescens & 90 & W Australia & $22-32^{\circ} \mathrm{S}$ & Coral and subtropical reefs & $5-30$ \\
\hline & Lachnolaimus maximus & 91 & Tropical W Atlantic & & & \\
\hline & Semicossyphus pulcher & 91 & NE Pacific & $23-37^{\circ} \mathrm{N}$ & Kelp forests, subtropical reefs & $1-55$ \\
\hline & Semicossyphus reticulatus & 100 & NW Pacific & $32-37^{\circ} \mathrm{N}$ & Subtropical to temperate reefs & $5-60$ \\
\hline Labrines & Tautoga onitis & 100 & NE Americas & $30-45^{\circ} \mathrm{N}$ & Boreal to temperate reefs & $1-75$ \\
\hline Cheilines & Cheilinus undulatus & $150^{\mathrm{b}}$ & Indo-Pacific & $30^{\circ} \mathrm{N}-35^{\circ} \mathrm{S}$ & Coral reefs & $2-65$ \\
\hline Julidines & Coris aygula & 120 & Indo-Pacific & $30^{\circ} \mathrm{N}-30^{\circ} \mathrm{S}$ & Coral reefs & $2-45$ \\
\hline \multirow[t]{8}{*}{ Scarines } & Bolbometopon muricatum & $140^{\mathrm{c}}$ & Indo-Pacific & $30^{\circ} \mathrm{N}-30^{\circ} \mathrm{S}$ & Coral reefs & $2-35$ \\
\hline & Cetoscarus bicolor & 90 & Indo-Pacific & $30^{\circ} \mathrm{N}-30^{\circ} \mathrm{S}$ & Coral reefs & $2-35$ \\
\hline & Scarus ghobban & 90 & Indo-Pacific, E Pacific & $30^{\circ} \mathrm{N}-32^{\circ} \mathrm{S}$ & Coral \& rocky reefs seagrass & $1-50$ \\
\hline & Scarus perrico & 76 & E Pacific & $28^{\circ} \mathrm{N}-10^{\circ} \mathrm{S}$ & Rocky \& coral reefs & $3-36$ \\
\hline & Scarus ovifrons & 78 & Tropical N Pacific & $22^{\circ} \mathrm{N}-30^{\circ} \mathrm{S}$ & Rocky reefs & $5-30$ \\
\hline & Scarus coelestinus & 77 & Tropical W Atlantic & $10^{\circ} \mathrm{N}-33^{\circ} \mathrm{N}$ & Coral reefs & $5-75$ \\
\hline & Scarus coeruelus & 120 & Tropical W Atlantic & $39^{\circ} \mathrm{N}-24^{\circ} \mathrm{S}$ & Coral reefs \& sand flats & $5-30$ \\
\hline & Scarus guacamaia & 120 & Tropical W Atlantic & $39^{\circ} \mathrm{N}-10^{\circ} \mathrm{S}$ & Coral reefs \& mangroves & $1-30$ \\
\hline
\end{tabular}


by shifting of the age of transition and by rapid growth of recently transformed males. Sadovy et al. (2004) present information on male size distribution that suggests some flexibility in the size at sexual transition. The age at first maturity ( 5 to $7 \mathrm{yr}$ ) is relatively late, representing $20 \%$ of the female life span as opposed to 5 to $6 \%$ of the female life span observed in other reef fishes with life spans in excess of $30 \mathrm{yr}$ (Choat \& Robertson 2002). However initial observations of spawning behaviour by $C$. undulatus suggest that small individuals ( $\sim 5 \mathrm{~cm}$ FL) are involved in pair spawning episodes with very large males (R. Fitzpatrick pers. comm.).

Three features of Cheilinus undulatus biology appear to be of major significance in terms of response to fishing. Firstly, as expected from the negative relationship between size and abundance in reef fishes (Dulvy et al. 2003) adult C. undulatus are relatively rare even in undisturbed habitats. Sadovy et al. (2004) record densities of approximately 10 ind. $\mathrm{ha}^{-1}$ in unfished areas and 4 to 5 ind. in lightly fished areas. High abundance records of up to 27 ind. ha $^{-1}$ (Sadovy et al. 2004) require confirmation. Secondly, the size at age distribution confirms that not all individuals change sex and the oldest members of the population are females in the 80 to $90 \mathrm{~cm}$ range. These individuals have very large ovaries (Fig. 7) and have the potential to contribute significantly to the overall reproductive output of the population. However as the size distributions from catch records (Fig. 1) and underwater surveys demonstrate (Fig. 6; Sadovy et al. 2004) individuals in this size range are extremely rare. Thirdly, the shallow depth range ( to $30 \mathrm{~m}$ ) of this species, the tendency to occupy shallow sleeping sites on reef fronts and an aggregative and highly visible spawning behaviour make it accessible to fishing at all stages of its adult life cycle.

This study establishes the age-based demographic information that will provide a framework for understanding the capacity of this species to respond to fishing impacts and other disturbances. Four additional areas of research are identified: (1) a more comprehensive analysis of the reproductive biology including histological studies to confirm the estimates of size and age of first female maturity and the mechanism of male recruitment, (2) estimates of age and sex-specific growth rates, life spans and mortality rates from other localities including the western pacific and the Indian Ocean, (3) abundance and size estimates based on a standardised methodology partitioned by habitat from a range of localities including the western Pacific and the Indian Ocean and (4) a more detailed analysis of the demographic and abundance data to provide a framework for predicting responses of Cheilinus undulatus populations to variations in fishing rates. These studies are ongoing.
Acknowledgements. We thank R. Stewart, M. Peterson and the field team of the ELF (Effects of Line Fishing program, $\mathrm{CRC}$ ) for assistance in the collection and processing of many of the line-caught fish; A. Ayling for providing the information from the transect counts; W. Robbins, J. Kritzer, A. Ayling, R. Pears, L. Bay, and L. Axe for providing assistance with the field work and laboratory processing; D. Welch and A. Smith for samples from the recreational fishery; H. Meeks and L. Squire for specimens from the commercial fishery; and J. Morrison and the JCU MARFU (Marine Facilities Unit) for providing and maintaining the aquarium facilities necessary for the validation experiments. The study benefited from discussions with G. Russ, J. Kritzer, A. Green, R. Hamilton, Y. Sadovy and R. Fitzpatrick. We acknowledge financial support from the Cooperative Research Centre for the Great Barrier Reef World Heritage Area, the Fisheries Research and Development Corporation, the Great Barrier Reef Marine Park Authority, a Queensland Government/Smithsonian Institution collaborative grant to J.H.C., D. R. Robertson, and an ARC and JCU internal grants to J.H.C. This research was carried out under Great Barrier Reef Marine Park Authority permits G99/177, G00/398, G01/386, G01/606, G03/7181.1 to J.H.C. and G98/292 and QFS PRM 00083C to the CRC Effects of Line Fishing program, as well as under JCU ethics approvals A503, A504 to J.H.C. and A857 to C.R.D. N. Dulvy and 2 anonymous reviewers provided valuable comments on the initial ms.

\section{LITERATURE CITED}

Cailliet GM, Andrews AH, Burton EJ, Watters DL, Kline DE, Ferry-Graham LA (2001) Age determination and validation studies of marine fishes: do deep-dwellers live longer? Exp Gerontol 36:739-764

Cappo M, Eden P, Newman SJ, Robertson S (2000) A new approach to validation of periodicity and timing of opaque zone formation in the otoliths of eleven species of Lutjanus from the central Great Barrier Reef. Fish Bull 98:474-488

Charnov EL (1993) Life history invariants: some explorations of symmetry in evolutionary ecology. Oxford University Press, Oxford

Choat JH, Axe LM (1996) Growth and longevity in acanthurid fishes; an analysis of otolith increments. Mar Ecol Prog Ser 134:15-26

Choat JH, Clements KD (1992) Diet in odacid and aplodactylid fishes from Australia and New Zealand. Aust J Mar Freshw Res 43:1451-1459

Choat JH, Robertson DR (2002) Age-based studies on coral reef fishes. In: Sale PF (ed) Coral reef fishes. Dynamics and diversity in a complex ecosystem. Academic Press, San Diego, CA

Choat JH, Axe LM, Lou DC (1996) Growth and longevity in fishes of the family Scaridae. Mar Ecol Prog Ser 145:33-41

Choat JH, Robertson DR, Ackerman J, Posada J (2003) An age-based demographic analysis of the Caribbean stoplight parrotfish Sparisoma viride. Mar Ecol Prog Ser 246: 265-277

Clements KD, Alfaro ME, Fessler J, Westneat MW (2004) Relationships of the temperate Australasian labrid fish tribe Odacini (Perciformes; Teleostei). Mol Phylogenet Evol 32:575-587

Cooper RA (1967) Age and growth of the tautog, Tautoga onitis (Linnaeus) from Rhode Island. Trans Am Fish Soc 96:134-142

Craig PC (1999) The von Bertalanffy growth curve: when a good fit is not enough. Naga 22:28-30 
Dulvy NK, Sadovy Y, Reynolds JD (2003) Extinction vulnerability in marine populations. Fish Fish Ser 4:25-64

Ferreira BP, Russ GR (1994) Age validation and estimation of growth rate in the coral trout, Plectropomus leopardus (Lacepede 1802) from Lizard island northern Great Barrier Reef. Fish Bull 92:46-57

Froese R, Pauly D (2000) FishBase 2000: concepts, design and data sources. ICLARM, Manila

Gomon MF (1997) Relationships of fishes of the labrid tribe Hypsigenyini. Bull Mar Sci 60:789-871

Gordoa A, Moli B, Raventos N (2000) Growth performance of 4 wrasse species on the north-western Mediterranean coast. Fish Res 45:43-50

Grant EM (1997) Grant's guide to fishes. EM Grant, Redcliffe

Halpern BS, Warner RR (2002) Marine reserves have rapid and lasting effects. Ecol Lett 5:361-366

Hilborn R, Walters CL (1992) Quantitative fisheries stock assessment: choice, dynamics and uncertainty. Chapman \& Hall, London

Hostetter EB, Munroe TA (1993) Age, growth, and reproduction of tautog Tautoga onitis (Labridae: Perciformes) from coastal waters of Virginia. Fish Bull 91:45-64

Jennings S, Reynolds JD, Polunin VC (1999) Predicting the vulnerability of tropical reef fishes to exploitation with phylogenies and life histories. Conserv Biol 13:1466-1475

Kaufman LS, Liem KF (1982) Fishes of the suborder Labroidei (Pisces: Perciformes): phylogeny, ecology and evolutionary significance. Breviora 472:1-19

Lowry M (2003) Age and growth of Cheilodactylus fuscus, a temperate reef fish. NZ J Mar Freshw Res 37:159-170

Parenti P, Randall JE (2000) An annotated checklist of the species of the labroid fish families Labridae and Scaridae. Ichthyol Bull (JLB Smith Inst) 68:1-97

Marshall TC (1966) Tropical fishes of the Great Barrier Reef. Angus \& Roberstson, Sydney

Meekan MG, Ackerman JL, Wellington GM (2001) Demography and age structures of coral reef damselfishes in the tropical eastern Pacific Ocean. Mar Ecol Prog Ser 212: 223-232

Munday PL, Jones GP (1998) The ecological implications of small body size among coral-reef fishes. Oceanogr Mar

Editorial responsibility: Otto Kinne (Editor-in-Chief), Oldendorf/Luhe, Germany
Biol Annu Rev 36:373-411

Newman SJ, Williams DMcB, Russ GR (1996) Age validation, growth and mortality rates of the tropical snappers (Pisces: Lutjanidae) Lutjanus adetii (Castelnau, 1873) and L. quinquelineatus (Bloch, 1790) from the central Great Barrier Reef, Australia. Mar Freshw Res 47:575-584

Newman SJ, Cappo M, Williams DMcB (2000) Age, growth, mortality rates and corresponding yield estimates using otoliths of the tropical red snappers, Lutjanus erythropterus, L. malabaricus and L. sebae, from the central Great Barrier Reef. Fish Res 48:263-275

Norman JR (1966) A draft synopsis of the orders, families and genera of recent fishes and fish-like vertebrates. British Museum (Natural History), London

Randall JE (1955) The coastal fishes of Oman. University of Hawaii Press, Honolulu, HI

Randall JE, Head SM, Sanders APL (1978) Food habits of the giant humphead wrasse, Cheilinus undulatus (Labridae) Environ Biol Fish 3:235-238

Roberts CM, Hawkins JP (1999) Extinction risk in the sea. TREE 14:241-246

Roff DA (1992) The evolution of life histories: theory and analysis. Chapman \& Hall, New York

Russ GR, Alcala AC (2004) Marine reserves: long-term protection is required for full recovery of predatory fish populations. Oecologia 138:622-627

Sadovy YJ, Vincent ACJ (2003) Ecological issues and the trades in live reef fishes. In: Sale PF (ed) Coral reef fishes. Dynamics and diversity in a complex ecosystem. Academic Press, San Diego, CA, p 391-420

Sadovy Y, Kulbicki M, Labrosse P, Letourneur Y, Lokani P, Donaldson TJ (2003) The humphead wrasse, Cheilinus undulatus: synopsis of a threatened and poorly known giant coral reef fish. Rev Fish Biol Fish 13:327-364

Westneat MW (1993) Phylogenetic relationships of the tribe Cheilinini (Labridae:Perciformes). Bull Mar Sci 52:351-394

Westneat MW, Alfaro ME (2005) Phylogenetic relationships and evolutionary history of the reef fish family Labridae. Mol Phylogenet Evol 36(2):370-390

Submitted: October 11, 2004; Accepted: January 10, 2006

Proofs received from author(s): July 6, 2006 